Review

\title{
Fruit and Vegetable Co-Products as Functional Feed Ingredients in Farm Animal Nutrition for Improved Product Quality
}

\author{
Eleni Kasapidou ${ }^{1, *}$, Evangelia Sossidou ${ }^{2}$ and Paraskevi Mitlianga ${ }^{1}$ \\ 1 Department of Agricultural Technology, Division of Agricultural Products Quality Control, \\ Technological Education Institute of Western Macedonia, 53100 Terma Kontopoulou, Florina, \\ Greece; E-Mail: pmitliagka@teiwm.gr \\ 2 Hellenic Agricultural Organization-DEMETER, Veterinary Research Institute of Thessaloniki, \\ 57001 Thermi, Thessaloniki, Greece; E-Mail: sossidou.arig@nagref.gr \\ * Author to whom correspondence should be addressed; E-Mail: ekasapidou@teiwm.gr; \\ Tel.: +30-6977-348326; Fax: +30-23850-54621.
}

Academic Editor: Stephen R. Smith

Received: 21 July 2015 / Accepted: 10 October 2015 / Published: 21 October 2015

\begin{abstract}
There are significant environmental, economic and social factors favoring the reutilization of fruit and vegetable processing co-products in farm animal nutrition. Current evidence shows that fruit and vegetable processing co-products can be effectively used in farm animal nutrition as functional feed ingredients for the production of food products of improved quality. These ingredients comply with consumer requests for the production of "clean," "natural" and "eco/green" label food products. The main parameters affecting extensive application of fruit and vegetable processing by-/co-products as functional feed ingredients in livestock nutrition are related to animal factors, logistics, and commercial value. Further research is needed to enable the commercial application of these products to livestock nutrition.
\end{abstract}

Keywords: fruit and vegetable co-products; farm animals; nutrition; product; quality

\section{Introduction}

Recently, there has been great social and environmental pressure for the efficient reutilization of agricultural industry residues [1,2] due to the global intensification of food production that has led to 
the creation of large quantities of food co-products and wastes [3]. Utilization of agroindustrial by-/co-products in farm animal nutrition reduces the environmental impact of the food industry and improves profitability and valorization of the agricultural by-products since feeding food residue to livestock is an efficient way to upgrade low quality materials into high quality foods [4]. This is compliant with the current legislation that strongly encourages the food industry to find new end-uses for by-products [5,6]. Furthermore, these undesirable materials pose increasing disposal and potentially severe pollution problems and represent a loss of valuable biomass and nutrients [7]. In addition, industrial ecology and circular economy are considered the leading principles for eco-innovation focusing on a "zero waste" society and economy where wastes can be used as raw materials [8]. On the other hand, consumers that demand the production of "clean," "natural" and "eco/green" label food products [9-12] are also willing to pay significant premiums for such products. Consumers also request natural ingredients, which consumers expect to be safe and health promoting due to their increasing awareness of diet related health problems [13]. Finally, feed additives can also affect other major determinants of food quality for the modern consumer such as shelf life, sensory characteristics (appearance and eating quality), nutritional value, and health enhancers [14-16].

Industrialization of food production has resulted in a generation of large quantities of food waste that can be classified into the following six categories: (a) crop waste and residues; (b) fruit and vegetables by-products; (c) sugar, starch and confectionary industry by-products; (d) oil industry by-products; (e) grain and legume by-products; and (f) distilleries' and breweries' by-products [17]. Processing of fruit, vegetable and oilseed (considered fruits) generates various quantities and types of by-products depending on the raw material and the applied processing procedure. For most fruits and vegetables, the production of likely waste is estimated to be approximately $30 \%$ of the processed material (Table 1) [18]. Furthermore, the global market for feed ingredients is expected to grow at the compound annual rate of $3.8 \%$ in the coming years and is projected to reach approximately $\$ 20$ million by 2018 [19] as a result of the rising per capita incomes and urbanization in developing countries [20]. Additionally, developments in the biorefinery industry and novel extraction methods have led to the production of phytochemicals and other target compounds that can be used as functional additives in different products [21,22].

Fruit and vegetable processing by-/co-products are promising sources of valuable substances such as phytochemicals (carotenoids, phenolics, and flavonoids), antioxidants, antimicrobials, vitamins, or dietary fats that possess favorable technological activities or nutritional properties [13,23]. The applications and the functions of fruit and vegetable residues or their valuable extractable compounds in the food industry are presented in key review studies [7,13,21,24,25]. Fruit and vegetable processing residues have traditionally been used in animal nutrition as the main feed ingredients and their effect on animal performance has been extensively studied [1,26,27]. However, fruit and vegetable processing by-/co-products as sources of phytochemicals constitute a relatively new class of feed ingredients and there is limited knowledge on their applications and functions as well as their bioactivity, bioavailability, and interactions with other feed ingredients. The aim of this study is to provide a brief overview of the recent knowledge on the application of fruit and vegetable co-/by-products as functional feed ingredients in farm animal nutrition for the production of food products with improved characteristics. Current limitations as well as targets for future research work are also discussed. 
Table 1. Percentage of food wastes and by-products in fruit and vegetable production $[18,28]$.

\begin{tabular}{cc}
\hline Production Process & Waste and by-Products (\%) \\
\hline White wine production & $20-30$ \\
Red wine production & $20-30$ \\
Fruit and vegetable juice production & $30-50$ \\
Fruit and vegetable processing and preservation & $5-30$ \\
Vegetable oil production & $40-70$ \\
Sugar production from sugar beet & 85 \\
\hline
\end{tabular}

\section{Definition of Fruit and Vegetable Co-/By-Products in Animal Nutrition}

In this overview, the definition of fruit and vegetable co-products includes all products derived from the various stages of fruit and vegetable processing that are suitable for animal consumption and promote welfare and health, as well as human health and safety. According to the European Union Regulation EC 767/2009 [29], feed materials are defined as:

products of vegetable or animal origin, whose principal purpose is to meet animals' nutritional needs, in their natural state, fresh or preserved, and products derived from the industrial processing thereof, and organic or inorganic substances, whether or not containing feed additives, which are intended for use in oral animal-feeding either directly as such, or after processing, or in the preparation of compound feed, or as carrier of premixtures.

The distinction between by- and co-products is not always consistent and it usually takes place outside the animal feed industry, as it is related to the objectives of other parties involved in food processing [27]. In accordance with Article 5 of the Revised Waste Framework Directive [30], food industry by-products can be defined as materials:

resulting from a production process, the primary aim of which is not the production of that item only if the following conditions are met: (a) further use of the substance or object is certain; (b) the substance or object can be used directly without any further processing other than normal industrial practice; (c) the substance or object is produced as an integral part of a production process; and (d) further use is lawful, i.e., the substance or object fulfils all relevant product, environmental and health protection requirements for the specific use and will not lead to overall adverse environmental or human health impacts.

Plant materials exposed to various physical and chemical treatments for the extraction of economically important components can be characterized as co-products [31]. In this respect, citrus pulp - the solid residue that remains after squeezing the fruit for juice - is a by-product, whereas citrus molasses - the syrup produced by the concentration of juice released from the citrus peel-is a co-product. However, there are products such as fermented grape pulp that cannot be classified as either by- or co-products. In terms of animal feeding, the distinction between co- and by-products is not significant and not related to the nutritional value of these products. Therefore, for purposes of convenience, co-/byproducts will be referred to as co- products from henceforth. 


\section{Feed Additives for Improved Product Quality—Functional Ingredients from Fruit and Vegetable Co-Products}

In accordance to the European Food Safety Authority [32], feed additives for improved animal product quality can "favorably affect":

(a) the sensory characteristics and acceptance of the products, i.e., antioxidants and colorants,

(b) the nutritional value of the products, i.e., long chain polyunsaturated fatty acids, conjugated linoleic acid (CLA), and

(c) the microbial quality of the products.

It is also noted that, according to Article 17 of Regulation (EC) No 1831/2003 on additives for use in animal nutrition, the Commission has established the European Union Register of Feed Additives [33].

Fruit and vegetable co-products are heterogeneous products as their physical form (peels, seeds, stems, stones, pulp etc.), the processing technology of the raw material for the production of the food product, their storage, and handling conditions affect the composition and concentration of the target ingredients. For instance, tomato skins contain higher levels of lycopene in comparison to tomato seeds [34]. Additionally, mechanical peeling of tomatoes with sodium hydroxide increases the sodium content of tomato skins. In addition, the names of the co-products (pomace, pulp, cake, waste, etc.) may fail to provide an accurate description of the product ingredients and composition. Therefore, determination of the chemical composition of the co-product before application in livestock diets is suggested [35]. Some typical functional ingredients from fruit and vegetable co-products suitable for application in farm animal nutrition are presented in Table 2.

Table 2. Functional ingredients from fruit and vegetable processing co-products $[21,25]$.

\begin{tabular}{cc}
\hline Fruit or Vegetable & Functional Ingredient \\
\hline Apple skin/pomace & Polyphenols \\
\hline Orange peel & Hesperidin \\
\hline Orange pulp & Carotenoids \\
\hline Grape pomace/skin/seeds & Polyphenols \\
\hline Carrot peel & Polyphenols \\
& Carotenoids \\
\hline Tomato seeds & Unsaturated fatty acids \\
\hline Tomato skin & Carotenoids (lycopene) \\
\hline Potato peel & Polyphenols \\
\hline Red beet & Polyphenols \\
\hline Sunflower seed & Phytosterols \\
\hline Soybean seed & Phytosterols \\
\hline Olive pomace & Polyphenols \\
\hline
\end{tabular}

\section{Food-Feed-Food System Description}

The present food-feed-food system is shown in Figure 1. Fruit and vegetable industry co-products are collected either from primary production fields, such as in the case of olive leaves, or from the 
processing factories, such as with pomaces; they are then used either as unprocessed residue or are subjected to processing. Processing procedures may involve drying, since most of these materials have a high moisture content that leads to product spoilage, or they may be subjected to advanced processing/biorefinery techniques for the collection of specific compounds such as phenols, vitamins, fatty acids, or carotenoids. The moisture content of citrus fruits lies in the range of $76 \%-83 \%$ [27], olive cake moisture stands around 30\%-50\% [36], and the average moisture content of grape pomace is approximately $64 \%$ [37].

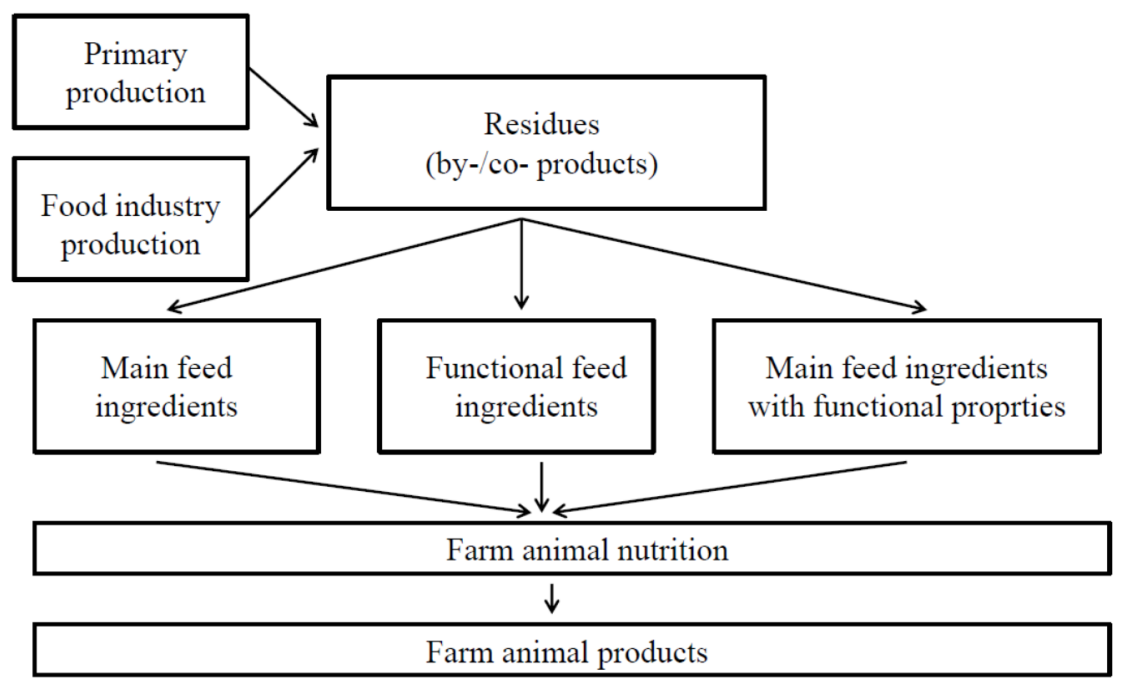

Figure 1. Simplified schematic presentation of the food-feed-food system.

The produced co-products can be incorporated in animal feed formulations either as main feed ingredients to provide crude protein and energy, such as citrus pulp, as dietary supplements to achieve a particular function, such as tomato pulp, as antioxidants or as dual purpose ingredients (main feed ingredients with functional properties), such as in the case of olive pomace. The food-feed-food cycle is completed by the production of primary (milk, meat, eggs) livestock products.

\section{Application of Dietary Fruit and Vegetable Co-Products on Farm Animal Product Quality}

Examples of successful applications of fruit and vegetable co-products, either as main feed ingredients or as dietary supplements on farm animal nutrition in relation to the quality characteristics, i.e., shelf life and nutritional value, are presented in Table 3. Literature research has primarily focused on the utilization of co-products such as grape, tomato, olive or citrus pomace that are voluminously produced [1] and have an important impact on the envinronment. Furthermore, research has narrowed in the years since 2000 to encompass both modern production trends in animal nutrition and novel techniques for the recovery of value-added components from food industry residues. Fruit and vegetable co-products have been mainly tested in poultry and small ruminant diets. There are also a few studies on the effects of dietary supplementation of fruit and vegetable co-products on meat quality from monogastric animals (pigs and rabbits) and cow milk. With regard to the intended function, these co-products have been mainly tested as antioxidants since lipid oxidation is a major parameter affecting the shelf life, sensory properties and the nutritional/health value of animal food products $[38,39]$, along with the fact that fruit and vegetable co-products are good sources of natural 
antioxidants due to their high phenolic content [40,41]. Another examined quality characteristic was the lipid profile of meat and milk from small ruminants. Production of milk and meat with lower concentrations of saturated fatty acids or increased concentrations of the nutritionally important conjugated linoleic acid (CLA) is related to the dietary recommendations for healthy fat intake [42] and it satisfies consumers' demands for healthier foods. In relation to the product form, in the vast majority of the studies, fresh or minimally processed, i.e., dried products have been used, whereas in a limited number of trials recovered components of high value such as grape seed extract or hesperidin have been used. The desirable functions of the examined co-products (i.e., grape or tomato pomace) on product quality have been validated in a number of studies, usually following a dose response pattern. However, lack of efficacy of the supplemental feed ingredient in relation to the intended function has also been reported in some cases. For example, O'Grady et al. [43] reported no effect of dietary grape seed extract on muscle lipid oxidation in pork meat, whereas Tsiplakou and Zervas [44] reported no increase in conjugated linoleic acid content in milk from goats supplemented with grape pomace (marc), in contrast to the positive effect observed in ewes. The main reason for the lack of effectiveness is considered to be related to inadequate supplementation levels, although other potential reasons have not been thoroughly explored. There are also cases wherein supplementation of animal diets with food and vegetable co-products had a negative effect on product quality. For instance, Francesch and Cartañà [45] reported undesirable changes in the odor and flavor of meat from Penedes chicken fed on a diet containing grape seeds.

\section{Limitations of Commercial Application of Fruit and Vegetable Co-Products in Animal Nutrition}

The three main parameters affecting the application of alternative feed ingredients in animal nutrition are related to animal factors and the presence of anti-nutritional factors, production logistics and profit that is extended from the food processing industry to the feed industry and, finally, to the farmer [76]. The same factors affect the application of fruit and vegetable co-products in livestock nutrition.

Incorporation of co-products in animal diets should support an acceptable animal performance, since adverse effects on production yields, even if associated with superior end product quality, will not allow their application in animal nutrition. For instance, lower concentrations and yields of milk fat have been reported in dairy cows fed on diets containing tomato seeds at certain inclusion levels, due to decreased digestibility of total fatty acids and crude protein [77]. Similarly, retarded growth has been observed in broilers fed on diets supplemented with grape seed extracts [78,79], also due to reduced protein digestibility [78]. Moreover, Yanez-Ruiz et al. [80] reported a difference in the digestive response between sheep and goats fed on diets containing condensed tannins from olive cakes. Therefore, commercial exploitation of fruit and vegetable co-products requires a detailed knowledge of the nutritional factors that can adversely affect animal performance and growth.

With regard to production logistics, there should be adequate product quantity to support a supply chain enabling incorporation in various types of feed formulations (matrices). Most of these products are seasonal and locally produced and thus they are fed to the animals either unprocessed, or after minor processing, i.e., drying. 
Table 3. Effects of fruit and vegetable processing co-products (either as bulk material or high value component) on farm animal product quality (selection divided by type of co-product and species).

\begin{tabular}{|c|c|c|c|}
\hline Co-/by Product or Extract & Animal Species & Effect $^{1}$ & References \\
\hline Grape pomace & Broilers & Antioxidant & {$[46,47]$} \\
\hline Grape seed extract & Broilers & Antioxidant & {$[48]$} \\
\hline Tomato extract & Broilers & Antioxidant & [48] \\
\hline Hesperidin & Broilers & Antioxidant & [49] \\
\hline Citrus pulp & Broilers & Improved fatty acid composition & {$[50]$} \\
\hline Pomegranate by-products & Broilers & $\begin{array}{c}\text { Antioxidant } \\
\text { Improved fatty acid composition } \\
\text { Hypocholesterolemic }\end{array}$ & [51] \\
\hline Hesperidin & Laying hens & Antioxidant & [52] \\
\hline Grape pomace & Laying hens & Antioxidant & [53] \\
\hline Grape seed/ Grape seed extract & Laying hens & Antioxidant & [54] \\
\hline Tomato pulp & Quails & Antioxidant & [55] \\
\hline Tomato powder & Quails & Antioxidant & {$[56]$} \\
\hline Tomato powder & Quails & Yolk colour enhancement & [57] \\
\hline Olive pomace & Rabbits & Antioxidant & [58] \\
\hline Tomato pomace & Rabbits & Improved fatty acid composition & [59] \\
\hline \multirow{2}{*}{ Olive pomace } & \multirow{2}{*}{ Pigs } & Antioxidant & \multirow{2}{*}[60]{} \\
\hline & & Improved fatty acid composition & \\
\hline Carob pulp & Pigs & $\begin{array}{c}\text { Antioxidant } \\
\text { Improved fatty acid composition }\end{array}$ & {$[61]$} \\
\hline Fermented grape pomace & Pigs & Improved fatty acid composition (subcutaneous fat) & [62] \\
\hline Tomato pomace & Ewes & Improved milk fatty acid composition & [63] \\
\hline Olive leaves & Ewes & Improved milk fatty acid composition & {$[63]$} \\
\hline Olive cake & Ewes & Improved milk fatty acid composition & {$[64,65]$} \\
\hline Tomato waste & Goats & Improved milk fatty acid composition & {$[66]$} \\
\hline Pomegranate seed pulp & Goats & Improved milk fatty acid composition & [67] \\
\hline Citrus (orange) pulp & Goats & Improved appearance, taste and texture (cheese) & [68] \\
\hline Pomegranate seed pulp & Kids & Antioxidant & [69] \\
\hline Pomegranate by-product silage & Lambs & Improved milk fatty acid composition & [70] \\
\hline Olive cake & Lambs & Antioxidant & [71] \\
\hline Dried citrus pulp & Lambs & Antioxidant & {$[72,73]$} \\
\hline Pomegranate peel extract & Cows & Improved milk fatty acid composition & {$[74]$} \\
\hline Dried stoned olive pomace & Water buffaloes & Improved milk fatty acid composition & [75] \\
\hline
\end{tabular}

${ }^{1}$ Function on meat unless otherwise stated.

Finally, the value of the co-product should be sufficient to attract the producer of the product, the feed manufacturer, and the livestock producer who will use the product. The co-product should merit a reasonable profit for the fruit and vegetable industry, the feed industry and the livestock producers to enable its production in the first place. The relative economic value of the co-products should remain low to gain an advantage in a competitive market. Recent advances in the biorefinery technology of 
fruit and vegetable co-products have resulted in large volume production of ingredients such as lycopene, $\beta$-carotene, tocopherols, and polyphenols, with a relative low cost. Until now, plant derived phytochemicals have only been used primarily in pharmaceuticals, cosmetics, nutrition and food industries due to the high production cost [81].

Other factors limiting the application of co-product processing ingredients in animal nutrition is product inconsistency due to endogenous differences in their composition with respect to their botanical origin and processing conditions. The function of the co-product should be specific in order to survive competition in the feed ingredient market. The lack of documentation on the positive effects of these ingredients on animal performance and end product quality in large scale commercial trials is another factor restricting their usage. Complicated feed legislation and restrictions and the impact of added co-products on feed palatability [82] may also discourage animal nutritionists from using these types of feed ingredients. Regarding feed palatability, ingredients can enhance feed flavor, leading to increased feed consumption, or result in an aversion from feed when the taste is undesirable. The major factors and the requirements for the application of fruit and vegetable co-products in farm animal nutrition are presented in Table 4. Furthermore, Smits and Sijtsma [83] described a decision tree for the assessment of the technical and economic feasibility for the application of co-products in animal nutrition.

Table 4. Factors and requirements for the application of fruit and vegetable co-products in farm animal nutrition.

Factors

Seasonal and/or local supply

Adequate product quantity to support a supply chain

Collection, transportation and processing cost

Limited knowledge of processing, storage and handling conditions

Unknown effects on nutrient digestibility related to processing conditions and/or different feed formulations (matrices)

Product biosecurity and safety

Feed palatability and animal response to the diet

Variable product composition

Unknown production costs

Limited or no knowledge of inclusion levels-Application of "best guess" theory for feed formulation

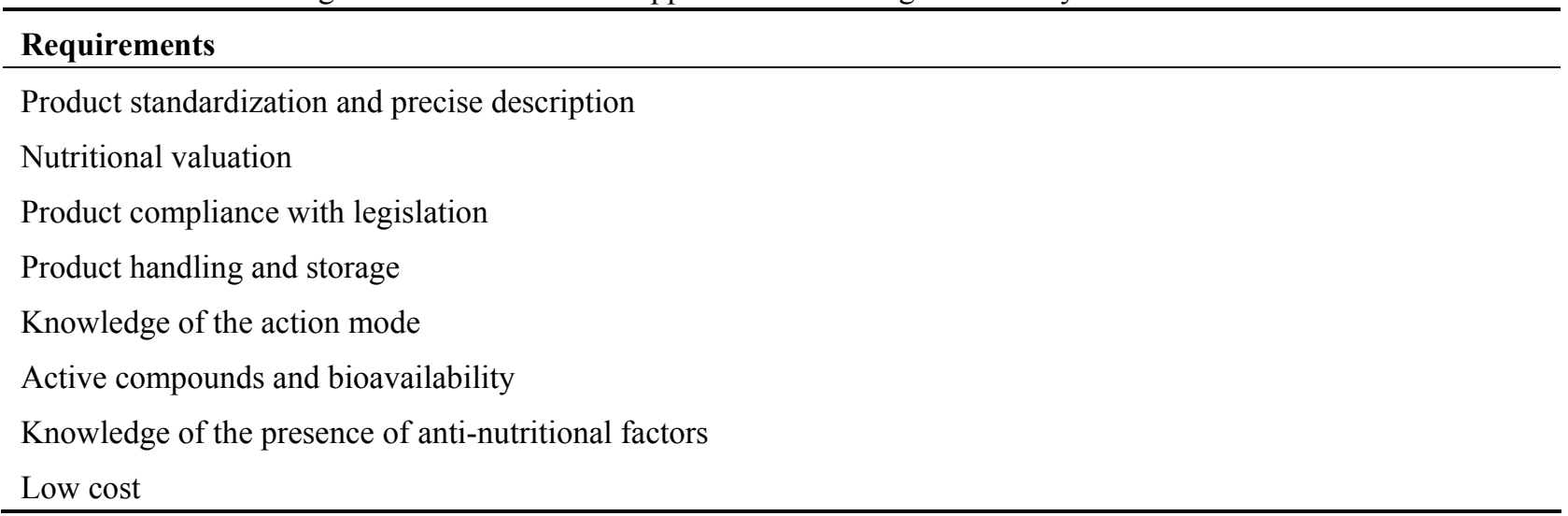


Recently, Wadhwa and Bakshi [84] published a report with useful information on the chemical composition, conservation methods, nutritive value, and guidelines for effective incorporation of fruit and vegetable residues in animal diets. Additionally, Laufenberg et al. [7] summarized the current utilization procedures of fruit and vegetable residues for their use in the feed industry.

\section{Concluding Remarks}

This overview highlighted the current developments on the application of fruit and vegetable processing co-products in farm animal nutrition as functional feed ingredients. The relevance of this topic is supported by the zero-waste society target set by the European Union until 2025 and the environmental burden arising both from fruit and vegetable processing and livestock production. In recent years, a number of studies have shown that fruit and vegetable processing co-products can be effectively used in livestock nutrition for the production of animal products of improved quality. Nevertheless, fruit and vegetable processing co-products still remain an underexploited source for the dietary supplementation of farm animals with functional compounds and the production of valueadded products. Commercial application of fruit and vegetable industry co-products as functional feed ingredients provides challenges and opportunities for field scientists. However, targeted multidisciplinary (food scientists, animal scientists, chemists) research on the efficacy, bioavailability, individual functions, and optimum supplementation levels of fruit and vegetable co-products as feed additives is needed.

\section{Future Research}

Future research should focus on:

- The effect of raw materials' processing conditions on the composition (characterization and quantification of the active/target compounds) of the produced co-products.

- The development of processing and biorefinery techniques that eliminate or negate hazardous constituents.

- The identification of synergistic and antagonistic functions of agricultural co-products with other feed ingredients in various types of feed formulations (matrices).

- The determination of optimum supplementation levels and the bioavailability of functional feed ingredients with relation to farm animal species and their required function.

- The production of affordable products with a standard composition that can be easily stored (extracts, powders) and have a reasonable shelf life.

- The evaluation of the functionality of new types of feed ingredients in large scale (commercial) feeding trials.

\section{Conflicts of Interest}

The authors declare no conflict of interest.

\section{References}

1. Pfaltzgraff, L.A.; Cooper, E.C.; Budarin, V.; Clark, J.H. Food waste biomass: A resource for high-value chemicals. Green Chem. 2013, 15, 307-314. 
2. Santana-Méridas, O.; González-Coloma, A.; Sánchez-Vioque, R. Agricultural residues as a source of bioactive natural products. Phytochem. Rev. 2012, 11, 447-466.

3. Waldron, K. Waste minimization, management and co-product recovery in food processing: An introduction. In Handbook of Waste Management and Co-Product Recovery in Food Processing; Waldron, K., Ed.; Woodhead Publishing Limited: Cambridge, UK, 2007; Volume 1, pp. 3-20.

4. Elferink, E.V.; Nonhebel, S.; Moll, H.C. Feeding livestock food residue and the consequences for the environmental impact of meat. J. Clean. Prod. 2008, 16, 1227-1233.

5. Panouillé, M.; Ralet, M.C.; Bonnin, E.; Thibault, J.F. Recovery and reuse of trimmings and pulps from fruit and vegetable processing. In Handbook of Waste Management and Co-Product Recovery in Food Processing; Waldron, K., Ed.; Woodhead Publishing Limited: Cambridge, UK, 2007; Volume 1, pp. 417-447.

6. European Commission. Innovating for sustainable growth: A bioeconomy for Europe. COM (212) 60 final. Available online: http://ec.europa.eu/research/bioeconomy/pdf/201202 innovating_sustainable_growth.pdf(accessed on 6 July 2015).

7. Laufenberg, G.; Kunz, B.; Nystroem, M. Transformation of vegetable waste into value added products: (A) the upgrading concept; (B) practical implementations. Bioresour. Technol. 2003, 87, 167-198.

8. Mirabella, N.; Castellani, V.; Sala, S. Current options for the valorization of food manufacturing waste: A review. J. Clean. Prod. 2014, 65, 28-41.

9. Burt, S. Essential oils: Their antibacterial properties and potential applications in foods-A review. Int. J. Food Microbiol. 2004, 94, 223-253.

10. Grunent, K.G. Food quality and safety: Consumer perception and demand. Eur. Rev. Agric. Econ. 2005, 32, 369-391.

11. Joppen, L. Taking out the chemistry. Food Eng. Ingred. 2006, 31, 38-41.

12. Karre, L.; Lopez, K.; Getty, K.J.K. Natural antioxidants in meat and poultry products. Meat Sci. 2013, 94, 220-227.

13. Schieber, A.; Stintzing, F.C.; Carle, R. By-products of plant food processing as a source of functional compounds-Recent developments. Trends Food Sci. Technol. 2001, 12, 401-413.

14. Bogue, J.; Coleman, T.; Sorenson, D. Determinants of consumers' dietary behaviour for health-enhancing foods. Br. Food J. 2005, 107, 4-16.

15. Bou, R.; Codony, R.; Tres, A.; Decker, E.A.; Guardiola, F. Dietary strategies to improve nutritional value, oxidative stability, and sensory properties of poultry products. Crit. Rev. Food Sci. Nutr. 2009, 49, 800-822.

16. Wenk, C. Recent advances in animal feed additives such as metabolic modifiers, antimicrobial agents, probiotics, enzymes and highly available minerals-Review. Asian-Australas. J. Anim. Sci. 2000, 13, 86-95.

17. Ajila, C.M.; Brar, S.K.; Verma, M.; Rao, U.P. Sustainable solutions for agro processing waste management: An Overview. In Environmental Protection Strategies for Sustainable Development, Malik, A., Grohmann, E., Eds., Springer Science/Business Media: Dordrecht, The Netherlands, 2012; pp. 65-109. 
18. De las Fuentes, L.; Sanders, B.; Lorenzo, A.; Alber, S. AWARENET: Agro-Food Wastes Minimisation and Reduction Network. In Total Food Exploiting Co-Products-Minimizing Waste-Workshop Report; Total Food Exploiting co-products-Minimizing waste; Proceedings Volume; Waldron, K.W., Faulds, C.B., Smith, A.C., Eds.; Institute of Food Research: Norwich, UK, 2004; pp. 233-244.

19. Anonymous. Animal Feed Additives Market Worth $\$ 20,233.2$ Million by 2018. Available online: http://www.marketsandmarkets.com/PressReleases/animal-feed.asp (accessed on 15 June 2014).

20. OECD/Food and Agriculture Organization of the United Nations. OECD-FAO Agricultural Outlook 2015; OECD Publishing: Paris, France, 2015.

21. Galanakis, C.M. Recovery of high added-value components from food wastes: Conventional, emerging technologies and commercialized applications. Trends Food Sci. Technol. 2012, 26, $68-87$.

22. Wijngaard, H.; Hossain, M.B.; Rai, D.K.; Brunton, N. Techniques to extract bioactive compounds from food by-products of plant origin. Food Res. Int. 2012, 46, 505-513.

23. Fernández-López, J.; Sendra, E.; Sayas-Barberá, E.; Navarro, C.; Pérez-Alvarez, J.A. Physico-chemical and microbiological profiles of "salchich" (Spanish dry-fermented sausage) enriched with orange fiber. Meat Sci. 2008, 80, 410-417.

24. Ayala-Zavala, J.F.; Vega-Vega, V.; Rosas-Domínguez, C.; Palafox-Carlos, H.; Villa-Rodriguez, J.A.; Siddiqui, M.W.; Dávila-Aviña, J.E.; González-Aguilar, G.A. Agro-industrial potential of exotic fruit byproducts as a source of food additives. Food Res. Int. 2011, 44, 1866-1874.

25. Oreopoulou, V.; Tzia, C. Utilization of plant by-products for the recovery of proteins, dietary fibers, antioxidants, and colorants. In Utilization of by-Products and Treatment of Waste in the Food Industry; Oreopoulou, V., Winfried, R., Eds.; Springer: New York, NY, USA, 2007; pp. 209-232.

26. Bampidis, V.A.; Robinson, P.H. Citrus by products as ruminant feeds: A review. Anim. Feed Sci. Technol. 2006, 128, 175-217.

27. Crawshaw, R. Co-Product Feeds: Animal Feeds from the Food and Drinks Industries; Nottingham University Press: Nottingham, UK, 2001.

28. AWARENET. Handbook for the Prevention and Minimisation of Waste and Valorisation of By-Products in European Agro-Food Industries; Deposito legal BI-223-04; AWARENET: Grahamstown, South Africa, 2004.

29. European Union. Regulation No 767/2009 of the European Parliament and of the Council of 13 July 2009 on the placing on the market and use of feed. Off. J. Eur. Union 2009, L229, 1-28.

30. European Union. Directive No 2008/98 of the European Parliament and the Council of 19 November 2008 on Waste and Repealing Certain Directives. Off. J. Eur. Union 2008, L312, 3-30.

31. Serena, A.; Knudsen, K.E. Chemical and physicochemical characterisation of co-products from the vegetable food and agro industries. Anim. Feed Sci. Technol. 2007, 139, 109-124.

32. European Food Safety Authority. Scientific Opinion of the Panel on Additives and Products or Substances used in Animal Feed (FEEDAP) on functional groups of additives as described in Annex 1 of Regulation (EC) No 1831/2003. EFSA J. 2008, 920, 1-19. 
33. European Union Register of Feed Additives pursuant to Regulation (EC) No 1831/2003. Available online: http://ec.europa.eu/food/food/animalnutrition/feedadditives/legisl_en.htm (accessed on 6 October 2015).

34. Knoblich, M.; Anderson, B.; Latshaw, D. Analyses of tomato peel and seed byproducts and their use as a source of carotenoids. J. Sci. Food Agric. 2005, 85, 1166-1170.

35. Feedipedia. Animal Feed Resources Information System. Available online: http://www.feedipedia. org (accessed on 31 August 2015).

36. López, M.J.; Moreno, J.; Ramos-Cormenzana, A. The effect of olive mill wastewaters variability on xanthan production. J. Appl. Microbiol. 2001, 90, 829-835.

37. Makris, D.P.; Boskou, G.; Andrikopoulos, N.K. Polyphenolic content and in vitro antioxidant characteristics of wine industry and other agri-food solid waste extracts. J. Food Compos. Anal. 2007, 20, 125-132.

38. Jiménez-Colmenero, F.; Carballo, S.; Cofrades, S. Healthier meat and meat products: Their role as functional foods. Meat Sci. 2001, 59, 5-13.

39. Kanner, J. Dietary advanced lipid oxidation endproducts are risk factors to human health. Mol. Nutr. Food Res. 2007, 51, 1094-1101.

40. Rice-Evans, C.A.; Miller, J.; Paganga, G. Antioxidant properties of phenolic compounds. Trends Plant Sci. 1997, 2, 152-159.

41. Hygreeva, D.; Pandey, M.C.; Radhakrishna, K. Potential applications of plant based derivatives as fat replacers, antioxidants and antimicrobials in fresh and processed meat products. Meat Sci. 2014, 98, 47-57.

42. European Food Safety Authority. Scientific Opinion on Dietary Reference Values for fats, including saturated fatty acids, polyunsaturated fatty acids, monounsaturated fatty acids, trans fatty acids, and cholesterol. EFSA J. 2010, 8, 1461.

43. O’Grady, M.N.; Carpenter, R.; Lynch, P.B.; O’Brien, N.M.; Kerry, J.P. Addition of grape seed extract and bearberry to porcine diets. Influence on quality attributes of raw and cooked pork. Meat Sci. 2008, 78, 438-446.

44. Tsiplakou, E.; Zervas, G. The effect of dietary inclusion of olive tree leaves and grape marc on the content of conjugated linoleic acid and vaccenic acid in the milk of dairy sheep and goats. J. Dairy Res. 2008, 75, 270-278.

45. Francesch, A.; Cartañà, M. The effects of grape seed in the diet of the Penedes chicken, on growth and on the chemical composition and sensory profile of meat. Br. Poult. Sci. 2015, 56, 477-485.

46. Goñi, I.; Brenes, A.; Centeno, C.; Viveros, A.; Saura-Calixto, F.; Rebolé, A.; Arija, I.; Estevez, R. Effect of dietary grape pomace and vitamin $\mathrm{E}$ on growth performance, nutrient digestibility, and susceptibility to meat lipid oxidation in chickens. Poult. Sci. 2007, 86, 508-516.

47. Brenes, A.; Viveros, A.; Goñi, I.; Centeno, C.; Sáyago-Ayerdy, S.G.; Arija, I.; Saura-Calixto, F. Effect of grape pomace concentrate and vitamin $\mathrm{E}$ on digestibility of polyphenols and antioxidant activity in chickens. Poult. Sci. 2008, 87, 307-316.

48. Smet, K.; Raes, K.; Huyghebaert, G.; Haak, L.; Arnouts, S.; de Smet, S. Lipid and protein oxidation of broiler meat as influenced by dietary natural antioxidant supplementation. Poult. Sci. 2008, $87,1682-1688$. 
49. Simitzis, P.E.; Symeon, G.K.; Charismiadou, M.A.; Ayoutanti, A.G.; Deligeorgis, S.G. The effects of dietary hesperidin supplementation on broiler performance and chicken meat characteristics. Can. J. Anim. Sci. 2011, 91, 275-282.

50. Mourão, J.L.; Pinheiro, V.M.; Prates, J.A.M.; Bessa, R.J.B.; Ferreira, L.M.A.; Fontes, C.M.G.A.; Ponte, P.I.P. Effect of dietary dehydrated pasture and citrus pulp on the performance and meat quality of broiler chickens. Poult. Sci. 2008, 87, 733-743.

51. Ahmed, S.T.; Islam, M.M.; Bostami, A.R.; Mun, H.S.; Kim, Y.J.; Yang, C.J. Meat composition, fatty acid profile and oxidative stability of meat from broilers supplemented with pomegranate (Punica granatum L.) by-products. Food Chem. 2015, 188, 481-488.

52. Goliomytis, M.; Orfanou, H.; Petrou. E.; Charismiadou, M.A.; Simitzis, P.E.; Deligeorgis, S.G. Effect of hesperidin dietary supplementation on hen performance, egg quality and yolk oxidative stability. Br. Poult. Sci. 2014, 55, 98-104.

53. Kara, K.; Kocaoğlu Güçlü, B.; Baytok, E.; Şentürk, M. Effects of grape pomace supplementation to laying hen diet on performance, egg quality, egg lipid peroxidation and some biochemical parameters. J. Appl. Anim. Res. 2015, 44, 303-310.

54. Kaya, A.; Yildirim, B.A.; Kaya, H.; Gül, M.; Çelebi, S. The effects of diets supplemented with crushed and extracted grape seed on performance, egg quality parameters, yolk peroxidation and serum traits in laying hens. Eur. Poult. Sci. 2014, 78, doi:10.1399/eps.2014.59.

55. Botsoglou, N.; Papageorgiou, G.; Nikolakakis, I.; Florou-Paneri, P.; Giannenas, I.; Dotas, V.; Sinapis, E. Effect of dietary dried tomato pulp on oxidative stability of Japanese quail meat. $J$. Agric. Food Chem. 2004, 52, 2982-2988.

56. Sahin, N.; Orhan, C.; Tuzcu, M.; Sahin, K.; Kucuk, O. The effects of tomato powder supplementation on performance and lipid peroxidation in quail. Poult. Sci. 2008, 87, 276-283.

57. Karadas, F.; Grammenidis, E.; Surai, P.F.; Acamovic, T.; Sparks, N.H.C. Effects of carotenoids from lucerne, marigold and tomato on egg yolk pigmentation and carotenoid composition. Br. Poult. Sci. 2006, 47, 561-566.

58. Dal Bosco, A.; Mourvaki, E.; Cardinali, R.; Servili, M.; Sebastiani, B.; Ruggeri, S.; Mattioli, S.; Taticchi, A.; Esposto, S.; Castellini, C. Effect of dietary supplementation with olive pomaces on the performance and meat quality of growing rabbits. Meat Sci. 2012, 92, 783-788.

59. Peiretti, P.G.; Gai, F.; Rotolo, L.; Brugiapaglia, A.; Gasco, L. Effects of tomato pomace supplementation on carcass characteristics and meat quality of fattening rabbits. Meat Sci. 2013, 95, 345-351.

60. Doyle, S.P.; Harrison, K.R.; Daley, C.A.; Hamilton, P.C.; Sinnott, D.K. Effects of feeding olive pomace on the fatty acid profile of pork. Proc. West. Sect. Am. Soc. Anim. Sci. 2006, 57, 216-218.

61. Inserra, L.; Luciano, G.; Bella, M.; Scerra, M.; Cilione, C.; Basile, P.; Lanza, M.; Priolo, A. Effect of including carob pulp in the diet of fattening pigs on the fatty acid composition and oxidative stability of pork. Meat Sci. 2015, 100, 256-261.

62. Yan, L.; Kim, I.H. Effect of dietary grape pomace fermented by Saccharomyces boulardii on the growth performance, nutrient digestibility and meat quality in finishing pigs. Asian-Australas. J. Anim. Sci. 2011, 24, 1763-1770. 
63. Abbeddou, S.; Rischkowsky, B.; Richter, E.K.; Hess, H.D.; Kreuzer, M. Modification of milk fatty acid composition by feeding forages and agro-industrial byproducts from dry areas to Awassi sheep. J. Dairy Sci. 2011, 94, 4657-4668.

64. Vargas-Bello-Pérez, E.; Vera, R.R.; Aguilar, C.; Lira, R.; Peña, I.; Fernández, J. Feeding olive cake to ewes improves fatty acid profile of milk and cheese. Anim. Feed Sci. Technol. 2013, 184, 94-99.

65. Molina-Alcaide, E.; Yáñez-Ruiz, D.R. Potential use of olive by-products in ruminant feeding: A review. Anim. Feed Sci. Technol. 2008, 147, 247-264.

66. Romero-Huelva, M.; Ramos-Morales, E.; Molina-Alcaide, E. Nutrient utilization, ruminal fermentation, microbial abundances, and milk yield and composition in dairy goats fed diets including tomato and cucumber waste fruits. J. Dairy Sci. 2012, 95, 6015-6026.

67. Modaresi, J.; Fathi Nasri, M.H.; Rashidi, L.; Dayani, O.; Kebreab, E. Short communication: Effects of supplementation with pomegranate seed pulp on concentrations of conjugated linoleic acid and punicic acid in goat milk. J. Dairy Sci. 2011, 94, 4075-4080.

68. Salvador, A.; Igual, M.; Contreras, C.; Martínez-Navarrete, N.; del Mar Camacho, M. Effect of the inclusion of citrus pulp in the diet of goats on cheeses characteristics. Small Rumin. Res. 2014, $121,361-367$.

69. Emami, A.; Ganjkhanlou, M.; Nasri, M.F.; Zali, A.; Rashidi, L. Pomegranate seed pulp as a novel replacement of dietary cereal grains for kids. Small Rumin. Res. 2014, 123, 238-245.

70. Kotsampasi, B.; Christodoulou, V.; Zotos, A.; Liakopoulou-Kyriakides, M.; Goulas, P.; Petrotos, K.; Natas, P.; Bampidis, V.A. Effects of dietary pomegranate byproduct silage supplementation on performance, carcass characteristics and meat quality of growing lambs. Anim. Feed Sci. Technol. 2014, 197, 92-102.

71. Luciano, G.; Pauselli, M.; Servili, M.; Mourvaki, E.; Serra, A.; Monahan, F.J.; Lanza, M.; Priolo, A.; Zinnai, A.; Mele, M. Dietary olive cake reduces the oxidation of lipids, including cholesterol, in lamb meat enriched in polyunsaturated fatty acids. Meat Sci. 2013, 93, 703-714.

72. Inserra, L.; Priolo, A.; Biondi, L.; Lanza, M.; Bognanno, M.; Gravador, R.; Luciano, G. Dietary citrus pulp reduces lipid oxidation in lamb meat. Meat Sci. 2014, 96, 1489-1493.

73. Gravador, R.S.; Jongberg, S.; Andersen, M.L.; Luciano, G.; Priolo, A.; Lund, M.N. Dietary citrus pulp improves protein stability in lamb meat stored under aerobic conditions. Meat Sci. 2014, 97, 231-236.

74. Abarghuei, M.J.; Rouzbehan, Y.; Salem, A.Z.M.; Zamiri, M.J. Nitrogen balance, blood metabolites and milk fatty acid composition of dairy cows fed pomegranate-peel extract. Livest. Sci. 2014, 164, 72-80.

75. Terramoccia, S.; Bartocci, S.; Taticchi, A.; di Giovanni, S.; Pauselli, M.; Mourvaki, E.; Urbani, S.; Servili, M. Use of dried stoned olive pomace in the feeding of lactating buffaloes: Effect on the quantity and quality of the milk produced. Asian-Australas. J. Anim. Sci. 2013, 26, 971-980.

76. Williams, P.E.V. Alternative feed ingredients-Overview from an end-users perspective with specific reference to bioethanol co-products. Adv. Anim. Biosci. 2014, 5, 1.

77. Cassinerio, C.A.; Fadel, J.G.; Asmus, J.; Heguy, J.M.; Taylor, S.J.; DePeters, E.J. Tomato seeds as a novel by-product feed for lactating dairy cows. J. Dairy Sci. 2015, 98, 4811-4828. 
78. Chamorro, S.; Viveros, A.; Centeno, C.; Romero, C.; Arija, I.; Brenes, A. Effects of dietary grape seed extract on growth performance, amino acid digestibility and plasma lipids and mineral content in broiler chicks. Animal 2013, 7, 555-561.

79. Lau, D.W.; King, A.J. Pre- and post-mortem use of grape seed extract in dark poultry meat to inhibit development of thiobarbituric acid reactive substances. J. Agric. Food Chem. 2003, 51, 1602-1607.

80. Yáñez-Ruiz, D.R.; Molina-Alcaide, E. A comparative study of the effect of two-stage olive cake added to alfalfa on digestion and nitrogen losses in sheep and goats. Animal 2007, 1, 227-232.

81. Huang, H.J.; Ramaswamy, S. Separation and purification of phytochemicals as co-products in biorefineries. In Biorefinery Co-Products: Phytochemicals, Primary Metabolites and Value-Added Biomass Processing; Bergeron, C., Carrier, D.J., Ramaswamy, S., Eds.; John Wiley \& Sons, Ltd.: Chichester, UK, 2012; pp. 37-53.

82. Favreau-Peigné, A.; Baumont, R.; Ginane, C. Food sensory characteristics: Their unconsidered roles in the feeding behaviour of domestic ruminants. Animal 2013, 7, 806-813.

83. Smits, C.; Sijtsma, R. A decision tree for co-product utilization. Adv. Pork Prod. Proc. Banff Pork Semin. 2007, 18, 213-221.

84. Wadhwa, M.; Bakshi, M.P.S. Utilization of Fruit and Vegetable Wastes as Livestock Feed and as Substrates for Generation of Other Value-Added Products; Makkar, H.P.S., Ed.; FAO: Rome, Italy, 2013. Available online: http://www.fao.org/docrep/018/i3273e/i3273e.pdf (accessed on 30 August 2015).

(C) 2015 by the authors; licensee MDPI, Basel, Switzerland. This article is an open access article distributed under the terms and conditions of the Creative Commons Attribution license (http://creativecommons.org/licenses/by/4.0/). 